\title{
Comprehensive assessment of Hordeum vulgare in the northern forest-steppe of the Tyumen region
}

\author{
Julia Ivanova*, Maria Fomina, Sergei Belousov, and Natalia Sharapova \\ Federal State Institutions Federal Research Centre Tyumen Scientific Centre of Siberian Branch of \\ the Russian Academy of Sciences (Tyumen Scientific Centre SB RAS)86 st. Malygina, Tyumen, \\ 625026, Russia
}

\begin{abstract}
Barley (Hordeum vulgare L.) occupies more than $80 \%$ of the sown area of forage crops. Barley is widely cultivated in many areas with contrasting soil and climatic conditions; breeding varieties that are resistant to abiotic and biotic environmental stress factors is an important factor that would make it possible to obtain grain with the required nutritional and forage qualities. The creation of barley varieties is a promising area of breeding in the world. To create varieties, it is necessary to consider the main directions: early ripening and high yield. To create an early ripening, high-yielding variety and hybrid of spring barley with high technological qualities of grain, the leading role belongs to the scientifically grounded selection of the source material. The article presents the results of a 3-year collection samples' study from the world collection of the All-Russian Institute of Plants' Genetic Resources named after N.I. Vavilov (VIR).
\end{abstract}

\section{Introduction}

Barley is an important agricultural crop, one of the oldest cultivated plants in the history of mankind (Hordeum vulgare) $[1,2]$.

Barley covers about 91 million hectares around the world and is in the fourth place after major cereals (wheat, rice and corn) [2].

Spring barley is mainly cultivated in Russia. It occupies about a third of the world's sown area.

Barley grain is widely used for food purposes for the manufacture of pearl barley and peeled barley, as well as flour. The content of nutrients in barley grain: 12\% protein, 5.5 fiber, 64.6 - without nitrogenous extractive substances, 2.1 - fat, 13 - water, $2.8 \%$ - ash [3.4]. Combined fodder with the addition of barley grain is widely used by farmers; in addition to grain, barley straw is used for feed. On average in Russia, about $70 \%$ of barley is used for fodder purposes. $1 \mathrm{~kg}$ contains 1.27 fodder units and $100 \mathrm{~g}$ of digestible protein. Barley protein contains all essential amino acids, including especially deficient and the most valuable ones - lysine and tryptophan.

Spring barley is an early ripening and plastic crop with a wide variety of forms $[5,6]$.

\footnotetext{
*Corresponding author: averyasova-uliy@mail.ru
} 
In the Northern Trans-Urals, it is one of the main forage crops. However, it should be noted that in the Tyumen region this important grain fodder crop is relatively new. Until 1970, almost no barley was cultivated in the region. In recent years, it occupies about 100 thousand hectares [7]. Barley is sown mainly in the forest-steppe zone of the Tyumen region. However, the practice of advanced farms and the experience of state variety testing sites show that in most years, the soil and climatic conditions are favorable for barley cultivation in all agricultural zones of the Tyumen region $[8,9]$

Barley is an early ripening and plastic crop with a wide variety of forms. The high crop's adaptability to various conditions determines its wide distribution across all continents of the world $[10,11,12]$.

\section{Materials and methods}

The objects of research were 152 samples of spring barley. Most of the spring barley collection was represented by samples of Western European origin. The Russian assortment is represented mainly by local samples and varieties of the North-West region, the NonChernozem zone, Western and Eastern Siberia. The Abalak variety cultivated in the region was used as a standard.

The studies were carried out in 2016-2019 on the experimental field of the Research Institute of Agriculture of the Northern Trans-Urals (zone III - northern forest-steppe). The soil is gray forest, podzolized, heavy loamy. The hydrolytic acidity $(\mathrm{pH})$ of the salt extract 5.5-6.8. The thickness of the plough-layer is $18-30 \mathrm{~cm}$, the humus content in the soil (for absolutely dry matter) - $1.50-4.75 \%$. NO3 content - traces - 18.0; P2O5 - 7.6-18.0; K2O $8.0-25.7 \mathrm{mg} / 100 \mathrm{~g}$ of soil. The predecessor - clean fallow.

The meteorological conditions of the Tyumen region were unstable in terms of plants' supply with warmth and moisture. The 2016 growing season was warm with periodic precipitation. The first half of the 2017 growing season was cool and rainy, the second - dry and hot. The agro-climatic conditions of 2018 were very contrasting. The sum of active temperatures for the growing season amounted to $1824^{\circ} \mathrm{C}$ with a long-time annual average of $1844^{\circ} \mathrm{C}$, GTC - 1.68 with a long-term annual average of 1.31 , which determines the growing season as moisty. The start of the 2019 growing season was cool. It was dry in July, which accelerated the plants' development. Abundant shower rains at the end of July caused lodging of field crops.

\section{Results and discussion}

Barley is considered the earliest crop among cereals. The growing season varies depending on the variety and growing conditions.

Over the years of research (2016-2019), the growing season for collection samples varied from 62 to 79 days. According to the ripening degree, the collection barley samples were divided into 3 groups: early maturing with the growing season duration of 62-67 days - 54 pcs $(35.5 \%)$; mid-season - 68-73 days. - 50 pieces $(32.9 \%)$; late ripening - more than 74 days - 48 pieces $(31.6 \%)$. The variability of the growing season over the years of the study was $\mathrm{V}=3.46-6.01$.

Evaluating the growing season's duration of spring barley collection samples, it should be noted that the varieties of the Russian and Western European selection were represented mainly by the mid-season group (44 pieces and 26 pieces, respectively). Varieties from Scandinavian countries were represented by medium late varieties (10 pieces).

For the Tyumen region, the most interesting are early ripening and mid-season varieties. Over the years of studying collection samples of barley and breeding lines, early ripening 
samples were identified: SP 2-104 harv.2010 (Tyumen region), Omskiy 96 (Omsk region), Zhuldus (Kazakhstan), Amulet (Czech Republic), etc.

Resistance to lodging is due to ecological and geographical origin, and also depends on the genetic characteristics of the variety. Lodging negatively affects the growth and development of plants, depending on the degree and time of its manifestation.

Assessment of collection material for lodging resistance was carried out in 2016-2019. The average plant height was 71.2 to $93.5 \mathrm{~cm}$, the range of variation over the years of study was from $50 \mathrm{~cm}$ to $120 \mathrm{~cm}$. Resistance to lodging in collection samples of spring barley varied from year to year. In 2016-2017, lodging did not appear. The resistance to lodging of collection barley samples in 2018-2019 was influenced by strong winds and heavy rainfall; as a result, the average score over the years amounted to 2.4-2.6. The coefficient of variation varied from $20.6-56.5 \%$ (table 1 ).

Table 1. Influence of growing conditions on height and degree of lodging resistance in collection barley samples in the Northern Trans-Urals zone, Tyumen, 2016 -2019

\begin{tabular}{|c|c|c|c|c|c|c|}
\hline \multirow{2}{*}{ Years } & \multicolumn{2}{|c|}{ Plant height, cm } & \multirow{2}{*}{ V, \% } & \multicolumn{2}{|c|}{ Lodging resistance, score } & \multirow{2}{*}{ V, } \\
\cline { 2 - 3 } & Average & $\begin{array}{c}\text { Range of } \\
\text { variation }\end{array}$ & & Average & Range of variation & \\
\hline 2016 & - & - & - & 4.5 & $1.5-5.0$ & 20.6 \\
\hline 2017 & 93.5 & $60.0-120.0$ & 10.3 & 4.1 & $1.5-5.0$ & 54.1 \\
\hline 2018 & 71.2 & $50.0-89.0$ & 10.7 & 2.4 & $1.0-5.0$ & 38.4 \\
\hline 2019 & 77.7 & $60.0-100.0$ & 11.0 & 2.6 & $1.0-5.0$ & 56.5 \\
\hline
\end{tabular}

Based on the data obtained after the two-factor analysis, we can conclude that the genotype $\times$ environment interactions (GEI) $-69.8 \%$, environment (year) $-28.5 \%$ had a significant impact on the yield formation. The share of genetic variability influence was not significant (variety) and amounted to $1.7 \%$.

The yield of collection barley samples over the study years varied from 516.3 (2019) to 684.0 (2017). The coefficient of variation for this indicator amounted to $14.5-16.5 \%$. The range of yield variation over the study years ranged from $215.0-883.3 \mathrm{~g} / \mathrm{m}^{2}$ (Table 2).

Table 2. The influence of growing conditions on the yield of collection barley samples in the Northern Trans-Urals zone, Tyumen, 2016 -2019

\begin{tabular}{|c|c|c|c|}
\hline \multirow{2}{*}{ Years } & \multicolumn{2}{|c|}{ Crop yield, $\mathrm{g} / \mathrm{m}^{2}$} & \multirow{2}{*}{ Variation coefficient $(\mathrm{V}), \%$} \\
\cline { 2 - 3 } & average & range of variation & 16.5 \\
\hline 2016 & 611.0 & $215.0-810.0$ & 14.5 \\
\hline 2017 & 684.0 & $393.3-883.3$ & 15.2 \\
\hline 2018 & 578.0 & $360.0-744.0$ & 14.9 \\
\hline 2019 & 516.3 & $288.0-732.0$ & \\
\hline
\end{tabular}

Analyzing the data obtained as a result of experiment's establishment for four years (2016-2019), a negative correlation was traced for all years of research in yield with the duration of the growing season (sprouting - gold ripeness). The relationship between yield and lodging resistance was reliably positive for three years $(2016,2017,2019)$ of studying the spring barley collection; in 2018, lodging resistance was lower than in other years due to the large amount of precipitation and plant height (Table 2).

\section{Conclusions}

One of the tasks in barley breeding is a comprehensive quality improvement of the products obtained. This is a high grain yield, early ripening, indicators of grain quality, but one 
should also not forget about resistance to lodging, pests and diseases, since these factors contribute to obtaining a higher quality yield. As a result of the analysis, there was a negative correlation between the yield and the duration of the growing season (sprouting gold ripeness). The relationship between yield and lodging resistance was reliably positive. According to the analysis of variance, the greatest influence on the formation of yield was exerted by genotype $\times$ environment interactions (GEI) $-69.8 \%$, environment (year) $28.5 \%$. Studying the collection material of spring barley, we selected samples of interest for practical breeding: SP 2-104 harv.2010 (Tyumen region), Omskiy 96 (Omsk region), Zhuldus (Kazakhstan), Amulet (Czech Republic).

\section{Acknowledgements}

The work was carried out according to state order No. 121041600036-6

\section{References}

1. Yu. Ivanova, M. Fomina, I. Loskutov, Achievements of science and technology of the agro-industrial complex, 32(6), 38-41 (2018)

2. N.I. Aniskov, Spring barley in Western Siberia (selection, seed production, varieties), 338 (2010)

3. G. Batalova, Zonal Research Institute of Agriculture of the North-East, 465 (2008)

4. A.N. Surin, E.N. Lyakhova, Barley selection in Siberia (1993)

5. Yu. Ivanova, M. Fomina, A Yaroslavtsev, Bioscience research, 17(2), 1183-1185 (2020)

6. P. Vahamidis, A. Stefopoulou, V. Kotoulas, D. Lyra, N. Dercas, G. Field Crops Research 206, 115-127 (2017)

7. K. Steele, E. Dickin, M. Keerio, S. Samad, C. Kambona, R. Brook, W. Thomas, G. Frost G..Field Crops Research, 154, 31-39 (2013)

8. J. Ian, C. Young, P. Bounds, N. Paveley. Field Crops Research, 239, 124-134 (2019)

9. I. Loskutov, SSC RF VIR, 336 (2007)

10. C. Doehlert Douglas, Crop Prod., 5, 165-189 (2002)

11. D. Paton, In: Oats: chemistry and technology. Ed. F. H. Webster, 93-120 (1986)

12. M. Fomina, Achievements of science and technology of the agro-industrial complex, 29(10), 63-66 (2015) 